\title{
Anti-urolithiatic Activities of Macrotyloma uniflorum Mediated through Multiple Pathway
}

\author{
Vaibhavkumar Baldevbhai Patel ${ }^{1,2}$, Niyati Acharya ${ }^{3 *}$ \\ ${ }^{1}$ Institute of Pharmacy, Nirma University, Ahmedabad, Gujarat, INDIA. \\ ${ }^{2}$ SAL Institute of Pharmacy, Ahmedabad, Gujarat, INDIA. \\ ${ }^{3}$ Department of Pharmacognosy, Institute of Pharmacy, Nirma University, Ahmedabad, Gujarat, INDIA.
}

\begin{abstract}
Background: Macrotyloma uniflorum Linn. (Fabaceae) seeds are widely used for their diuretic and urolithiatic effects in India. The present study investigated the effect of $\mathrm{n}$-butanol fraction of $M$. uniflorum (nBFMU) on kidney stone using in vitro and in vivo method. Materials and Methods: Nucleation, crystal growth, crystal aggregation and crystal dissolution assays were performed for nBFMU. Two doses of nBFMU (400 and $800 \mathrm{mg} / \mathrm{kg}$ ) were studied for their diuretic activity and sodium oxalate ( $\mathrm{NaOx}$ ) $(70 \mathrm{mg} / \mathrm{kg}$, i.p) induced urolithasis in male Wistar albino rats. Determination of body and kidney weight, measurement of various biochemical parameters in biological samples and examination of histology of kidney at the end of experiment were also done. Results: nBFMU exhibited a concentration dependent inhibitory activity on nucleation and aggregation along with decreased number of crystals of calcium oxalate (CaOX) produced in metastable solutions of $\mathrm{CaOX}$ in the in vitro experiments. Co-administration of nBFMU with $\mathrm{NaOX}$ has significantly $(p<0.001)$ increased the urine volume and the level of calculus inhibitors like magnesium, citrate and decreased the level of calculus promoters like oxalate, calcium, urea and uric acid. nBFMU supplement also prevented the pathological changes in kidney and increased the glomerulus activity of the kidney. Conclusion: These results indicate that $\mathrm{nBFMU}$ showed significant activity in urolithiasis which might be due to its diuretic, $\mathrm{CaOX}$ crystal formation inhibitory effects and its ability to increase the levels of inhibitors and decrease the level of promoters of urolithiasis.
\end{abstract}

Key words: Diuresis, Kidney stone, Macrotyloma uniflorum, Sodium oxalate, Urolithiasis.

\section{INTRODUCTION}

Urolithiasis, the stone formation in urinary system is a common and painful disease, which was first noted at 4800 BEC in Egyptian mummies. In all over the world, approximately $4-15 \%$ of the human populations suffer from urinary stone. As per the survey of National Health and Nutrition Examination in 2012, 7.1\% of women and $10.6 \%$ of men were affected by kidney stone disease in United States. ${ }^{1}$ As per the epidemiological studies, men are more affected as compared to women and are more prevalent between 20-49 ages in both sexes. ${ }^{2}$ The recurrence rate at every year is $10-23 \%$, in that $50 \%$ occured in $5-10$ years and 75\% occurred in 20 years. Approximate $12 \%$ population of India is suffering with urolithiasis every year with the high incidence states denote as "Stone belt", i.e. Gujarat, Maharashtra, Rajasthan, Delhi, Punjab, Haryana. ${ }^{3}$ Since urolithiasis is a multifactorial disease, its etiology is very complex and highly unpredictable.

Management of urolithiasis mostly depends on stones size and its location in urinary system. In most of the cases stone are removed by surgical treatment like extreacorporeal shock wave lithotripsy, percutaneous nephrolithotomy, ureteroscopy but unfortunately stone recurrence was observed about $50 \%$ after removal by surgical treatment. ${ }^{4}$ Surgical treatments causes side effect such as hypertension, tubular necrosis, hemorrhage and fibrosis
Submission Date: 17-09-2019; Revision Date: 19-12-2019; Accepted Date: 08-01-2020

DOI: 10.5530/ijper.54.2.46 Correspondence: Dr. Niyati Acharya, Assistant Professor and Head, Department of Pharmacognosy, Institute of Pharmacy Nirma University Ahmedabad- 382481 Gujarat, INDIA. Phone: +919824513258 E-mail: niyati20103@gmail. com

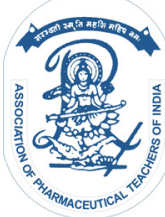

www.ijper.org 
of the kidney. ${ }^{5}$ Stone formation is a continues process and recurrence is very commonly observed, so there is an increased interest in the alternate supporting therapy for the management of urolithiasis using natural products and ayruvedic medicines. In Ayurveda, many traditional plants are reported to be used in the treatment of urolithiasis. Those traditional plants may offer complex spectrum of actions, like diuretic, analgesic, antimicrobial, anti-inflammatory, antispasmodic properties and litholytic and anticalcifying activities, without any major side effects. ${ }^{6}$

Macrotyloma uniflorum [Lam.] Verdc, commonly known as Horsegram is extensively cultivated, in India, Sri Lanka, Burma and Australia. However, the maximum genetic diversity region is considered to be in the Old World Tropics, especially in India and Himalayas. ${ }^{7}$ In India, Horsegram is one of the highly nutritious pulse crop with ethno-medicinal values, which is commonly known as Kulattha (Sanskrit), Kollu (Tamil), Kurti-kalai (Bengali), Muthira (Malayalam), Ullavallu (Telugu), Gahot (Kumaon and Garhwal) and etymologically, Gahot means" which destroys stone in initial stage"., In Southern India seed of Horse gram are known as a poor man's pulse. Consumption of cooked horse gram seeds with cooked rice is common in the rural people of India. ${ }^{10}$ According to Ayurveda, the seeds are acrid, bitter, acrid, dry, hot and used as anthelmintic, astringent, antipyretic and in the conditions such as uterine stones, asthma, tumors, bronchitis, hiccup, piles, urinary discharges, heart-troubles, intestinal colic and diseases of the brain and eyes, inflammation and liver troubles. ${ }^{9,11,12}$ Its decoction is used traditionally in menstrual dysfunctions and leucorrhoea. Furthermore, the cooked liquor of the horse gram seeds with spices is considered to be a potential remedy for the throat infection, common cold and fever. ${ }^{13}$ Decocation of M. uniflorum seeds with powder of Tephrosia purpurea used in kidney stone. ${ }^{14}$ Seeds of $M$. uniflorum contain proteins, carbohydrates, lipids, amino acids, falvonoids, phenolic acids, fatty acids, tannins, phytosterols, saponins, anthocyanidins and minerals like calcium, iron and molybdenum. Phenolic acids of $M$. uniflorum seeds are considered to be the most potent antioxidants which act by scavenging ROS and free radicals. The principal phenolic compounds of $M$. uniflorum seeds are flavonoids like quercetin, kaempferol and myricetin, vanillic, $\rho$-hydroxybenzoic and ferulic acids. ${ }^{15}$ Flavonoids like rutin, ${ }^{16}$ quercetin ${ }^{17}$ have been reported to prevent stone formation, decreased the stone deposition in kidney cell and prevent the oxidative stress. However, the potential bioactive components and the underlying mechanisms associated with treat urolithiasis are still unknown. The results of recent studies have shown that saponin of the plant could inhibit the formation of calcium oxalate $(\mathrm{CaOX})$ stones in vitro and in vivo, correlating with their antioxidant, anti-inflammatory, diuretic, antibacterial and other protective effects. Thus, the objective of present study is to evaluate the saponin rich fraction of M. uniflorum on experimentally induced $\mathrm{CaOX}$ crystallization via in vitro and in vivo methods.

\section{MATERIALS AND METHODS}

\section{Materials}

All chemicals used in experiment were of analytical grade. Standard drug Cystone (Himalaya Drug Company) purchased from local market of Ahmedabad. Calcium, Uric acid, Urea, Phosphorus, Creatinine, Uric acid (Accucare kits) estimation kits were procured from Lab-Care Diagnostics Pvt Ltd. Ahmedabad, Gujarat, India.

\section{Plant material and preparation of plant extract}

Dried seeds of M. uniflorum purchased in June 2016 from local market of Ahmedabad, Gujarat, India. Seeds were authenticated by Dr. B. L. Punjani, Ethnobotanist, Head, P.G. Center in Botany, Talod, Gujarat, India. The specimen was submitted to the Pharmacognosy department of Institute of Pharmacy, Nirma University. (Ref No. IPNSAVPMU2015) Dry seeds were grounded into the fine powdered by electric grinder. Powdered drug was stored in the tight container at ambient temperature for further use.

Powder of M. uniflorum (100 gm) seeds was refluxed with $500 \mathrm{ml}$ of petroleum ether for $24 \mathrm{hr}$. Layer of petroleum ether was collected and powder was again refluxed with methanol $(500 \mathrm{ml})$ for $24 \mathrm{hr}$. The extract was filtered and evaporated using a rotary vacuum evaporator at $50^{\circ} \mathrm{C}$, that collected dry extract $(7.45 \%$ $w / w)$ labelled as methanolic extract. Methanolic extract was solublised in water and again fractionated with dichloromethane, ethyl acetate and n-butanol (1:1 v/v) for $2 \mathrm{hr}$ at room temperature using separating funnel. n-butanol fraction was evaporated at room temperature and was labeled as nBFMU (n-butanol fraction of M. uniflorum $)(1.5 \% \mathrm{w} / \mathrm{w})$

\section{Phytochemical screening and quantitative estimation of phytoconstituents}

Phytochemical screening of nBFMU was carried out to identify the nature of phytoconstituents present in the extract. Total flavonoid content was measured using colorimetric assay of aluminum chloride. ${ }^{18}$ Total saponins were measured according to the method described by Obadoni and Ochuko. ${ }^{19}$ 


\section{In vitro experiments}

In vitro evaluation of $\mathrm{nBFMU}$ on $\mathrm{CaOX}$ crystallization was determined by the method described by Hennequin et $a .^{18}$ with some modification. Calcium chloride (1-5 mmol/ $/$ and sodium oxalate $(\mathrm{NaOX})(1-5 \mathrm{mmol} / \mathrm{l})$ solutions were prepared in a buffer containing $\mathrm{NaCl}$ $0.15 \mathrm{~mol} / \mathrm{l}$ and Tris- $\mathrm{HCl} 0.05 \mathrm{~mol} / \mathrm{l}$ at $p H 6.5$ for in vitro experiments

\section{Nucleation assay}

Nucleation assay was performed with some modification in method described by Hennequin et al. ${ }^{20}$ In this method $9 \mathrm{ml}$ of calcium chloride $(5 \mathrm{mmol} / \mathrm{l})$ solution was mixed with $1 \mathrm{ml}$ of nBFMU at different concentration $(250,500,750,1000,1250,1500 \mu \mathrm{g} / \mathrm{ml})$ and $9 \mathrm{ml}$ of $\mathrm{NaOX}$ at different concentrations of ranging from $(1-5 \mathrm{mmol} / \mathrm{ml})$ was added in each beaker. For standard drug (cystone) experiment, $1 \mathrm{ml}$ of cystone at different concentration $(250,500,750,1000,1250,1500 \mu \mathrm{g} / \mathrm{ml})$ was added in replace of nBFMU. Optical density of mixed solution was measured at $620 \mathrm{~nm}$ at room temperature and nucleation rate was estimated by comparing induction time in the presence of nBFMU with that of the control.

\section{Aggregation assay}

Aggregation assay has been performed using method described by Atmani and Khan ${ }^{21}$ with some modification. CaOX crystal seeds were prepared by mixing $\mathrm{NaOX}(50 \mathrm{mmol} / \mathrm{l})$ and $\mathrm{CaCl}_{2}(50 \mathrm{mmol} / \mathrm{l})$. Solutions were incubated at $60^{\circ} \mathrm{C}$ for $1 \mathrm{hr}$ in water bath and cooled at room temperature and kept it for overnight. $\mathrm{CaOX}$ crystals were harvested by centrifugation and then evaporated at $37^{\circ} \mathrm{C}$. CaOX crystals were used at a final concentration of $0.8 \mathrm{mg} / \mathrm{ml}$ in buffer solution containing Tris- $\mathrm{HCl} 0.05 \mathrm{~mol} / \mathrm{l}$ and $\mathrm{NaCl} 0.15 \mathrm{~mol} / \mathrm{l}$ at $p H$ 6.5. Assay was performed at room temperature in the presence and absence of nBFMU. The percentage inhibition of aggregation was calculated by comparing the turbidity in the presence of $\mathrm{nBFMU}$ and standard drug (cystone) at concentrations ranging from (250, $500,750,1000,1250,1500 \mu \mathrm{g} / \mathrm{ml})$ with that obtained in control using formula 1

$\%$ Inhibition of aggregation $=100$-Rate of aggregation $(\mathrm{IR})$

where, rate of aggregation is defined using equation 2
Rate of aggregation (IR) $=(($ Turbidity of sample $) /$

(Turbidity of control) $) \times 100$

\section{Crystal growth assay}

The percentage inhibition of $\mathrm{CaOX}$ crystal growth was evaluated in presence of $\mathrm{nBFMU}$ and cystone by adapting the procedure described by Chaudhary et al. ${ }^{22}$ with some modification. $1 \mathrm{ml}$ slurry of $\mathrm{CaOX}$ monohydrate crystals was mixed with $10 \mathrm{ml}$ of $2 \mathrm{mM}$ calcium chloride solution. Add immediately $10 \mathrm{ml}$ of $\mathrm{NaOX}$ solution in different concentrations (2, 2.5, 3, $3.5 \mathrm{mM})$. Consumption of oxalate immediately started after addition of $\mathrm{NaOX}$ and solution was stirred for $15 \mathrm{~min}$ using magnetic stirrer at $800 \mathrm{rpm}$ and absorbance was recorded at $214 \mathrm{~nm}$, with and without nBFMU and standard drug cystone at different concentration $(250,500,750,1000,1250,1500,2000 \mu \mathrm{g} / \mathrm{ml})$. The relative inhibitory activity was calculated using equation 3

$\%$ Relative Inhibitory Activity $=((\mathrm{C}-\mathrm{S}) / \mathrm{C}) \times 100$

Where ' $C$ is the rate of reduction of free oxalate without any extract and ' $S$ ' is the rate of reduction of free oxalate with the extract.

\section{Calcium oxalate dissolution}

$\mathrm{CaOX}$ crystal dissolution assay was performed as described by Saso et al..$^{23}$ followed with some minor modification. $\mathrm{CaOX}$ seeds were prepared as mentioned in the aggregation method above. A series of nBFMU solution from $250 \mu \mathrm{g} / \mathrm{ml}$ to $2000 \mu \mathrm{g} / \mathrm{ml}$ concentrations were prepared and $1 \mathrm{ml}$ of nBFMU solution was added to the $10 \mathrm{mg}$ of $\mathrm{CaOX}$ seeds in tubes followed by incubation at room temperature for overnight under mild mixing using vortex mixer. The tubes were centrifuged and seeds were washed, dried and weighted again. The ability of nBFMU to dissolve $\mathrm{CaOX}$ seeds was calculated using formula 4 .

$\%$ Crystal Dissolution $=(($ Intial Weight-Final Weight $) /$

$$
(\text { Intial Weight) }) \times 100
$$

\section{Animal study}

Adult Male Wistar albino rats (180-250 g) were housed at the animal house of Institute of Pharmacy, Nirma University, Ahmedabad, Gujarat, India under controlled environmental condition (temperature of $22-25^{\circ} \mathrm{C}$, relative humidity $(55 \pm 5 \%)$ and $12 \mathrm{hr}$ light-dark cycle) and animals have received food pellet and water ad libitum. The study protocol was approved by the Institutional Animal Ethics Committee of Institute of Pharmacy. (IP/PCOG/PHD/19/015, dated 28 July 2016) 


\section{Acute toxicity study}

The acute toxicity study was carried out in wistar male rats as per OECD guideline. Toxicity study was started from lower dose $1000 \mathrm{mg} / \mathrm{kg}$ followed by increasing dose depending on mortality to $2000 \mathrm{mg} / \mathrm{kg}, 4000 \mathrm{mg} / \mathrm{kg}$ and $6000 \mathrm{mg} / \mathrm{kg}$. Zero mortality was observed upto extract dose of $6000 \mathrm{mg} / \mathrm{kg}$.

\section{Determination of diuretic activity}

The diuretic activity of nBFMU was determined by method described by Lipschitz et al. ${ }^{24}$ Twenty Four healty rats (200-250 g) were selected and randomly divided into 4 groups with 6 animals in each group. All experimental animals were fasted for $18 \mathrm{hr}$ prior to the experiment and allocated only for water during the fasting period. Normal and standard groups were given saline $(20 \mathrm{ml} / \mathrm{kg}$ ) and hydrochlorothiazide (HCT) (10 $\mathrm{mg} / \mathrm{kg}$, as standard) respectively, while treated groups received the same $\mathrm{ml}$ of saline containing $400 \mathrm{mg} / \mathrm{kg}$ and $800 \mathrm{mg} / \mathrm{kg}$ of nBFMU, p.o. as a single dose. The rats were kept separately in metabolic cages. The urine was collected in cylinders at an interval of one hr for $6 \mathrm{hr}$. Total collected urine volume was measured.

\section{Sodium oxalate model of urolithiasis}

In $\mathrm{NaOX}$ model animals were divided into five groups (normal, disease control, standard and treatment groups with 2 doses of nBFMU) with 6 animals in each group. In normal group (Group I) animals were administered saline $(2.5 \mathrm{ml} / \mathrm{kg})$ and $70 \mathrm{mg} / \mathrm{kg} \mathrm{NaOX}$ in saline was administered intraperitoneally for 7 days to induce urolithiasis in all the animals expect normal group animals. ${ }^{25}$ The standard group (Group III) animals were administered Cystone $(750 \mathrm{mg} / \mathrm{kg}$, p.o.) for 7 days and Group IV and V (treatment group I and II respectively) were administered with nBFMU (400 $\mathrm{mg} / \mathrm{kg}$ and $800 \mathrm{mg} / \mathrm{kg}$, p.o.) respectively. Animal Body weights were recorded during the experiment and relative body weights (RBW) of animals were calculated using formula 5 as follow.

Relative body weight $=(($ Absolute body weight $) /($ Weight

$$
\begin{aligned}
& \text { at } 1^{\text {st }} \text { day of } \\
& \text { treatment })) \times 100
\end{aligned}
$$

Where, Absolute body weight was measured at one time interval.

Relative organ weight was calculated to compare the changes in the organ weight and calculated according to the equation 6 :

Relative organ weight $=(($ Organ weight $) /($ Body weight (at the last day) $)) \times 100$

\section{Urine collection and analysis}

On $8^{\text {th }}$ day, animals were kept in individual metabolic cages and $24 \mathrm{hr}$ urine samples were collected. The urinary $\mathrm{pH}$, urine volume and crystalluria were determined. Urine was acidified by addition of drop of concentrated hydrochloric acid and stored at $-20^{\circ} \mathrm{C}$ for determination of urea, calcium, uric acid, magnesium and phosphate using standard kits. The citrate and oxalate were estimated by the method described by Rajagopal ${ }^{26}$ and Hodgkinson ${ }^{27}$ respectively.

\section{Serum collection and analysis}

Blood was collected under light ether anesthetic condition from retro-orbital plexus by capillary method. Blood was centrifuged at $10,000 \mathrm{~g}$ for $10 \mathrm{~min}$ and serum was separated for the analysis of uric acid, calcium, magnesium, Blood Urea Nitrogen (BUN) and creatinine using diagnostic kits.

\section{Kidney histopathology and homogenate analysis}

The abdomen was incised, opened and both kidneys were removed from each animal of under study. Extraneous tissue was removed from isolated kidneys and kidneys were weighed and rinsed with ice-cold normal saline. One kidney was fixed with neutral formalin solution $(10 \% v / v)$ and after harvesting, horizontally sliced and sent to histology services (Accupath diagnostic laboratory, Ahmedabad, Gujarat, India.) for Hematoxylene and Eosin staining. The section of kidney were observed under microscope for examination of $\mathrm{CaOX}$ crystal depositions and the presence of $\mathrm{CaOX}$ crystal, tubular casts, glomerular congestion, interstitial edema, blood vessel congestion, epithelial adhesion and inflammatory cells. Another kidney was finely chopped and $20 \%$ of homogenate was prepared in Tris- $\mathrm{HCl}$ buffer at $p H$ 7.4. Kidney homogenate was used for determination of calcium, uric acid, phosphate, oxalate, urea, $\mathrm{LDH}$ and catalase.

\section{Statistical analysis}

Results data were expressed as mean \pm SEM. The results among the groups were analysed by one-way ANOVA followed by Dunnett's test using Graphpad Prism version 6 . Results were consider significant when value of $p<0.05$ or $p<0.001$.

\section{RESULTS}

\section{Phytochemical screening and quantitative estimation of phytoconstituents}

The nBFMU was qualitatively analysised for various phytoconstitutents using chemical tests. The study revealed that presence of flavonoid, saponin, carbohydrates, 
phytosterols and phenolic compounds. The total flavonoid content of nBFMU was found to be $7.52 \pm 0.40 \mathrm{mg}$ quercetin equivalents/g of extract. Total saponin content of the powdered drug was found to be $30.32 \pm 0.62 \mathrm{mg}$ diosgenin equivalent/g of extract.

\section{In vitro study}

In Nucleation assay, in control group as the concentration of oxalate was increased the nucleation rate was increased and in treatment group as the concentration of oxalate was increased the nucleation rate was decreased in dose depended manner. In lower concentration of $\mathrm{NaOx}(2 \mathrm{mM}), \mathrm{nBFMU}$ showed the maximum inhibition (55.43 $\pm 0.55 \%)$ at higher dose $(1500 \mu \mathrm{g} / \mathrm{ml})$ where at lower dose $(250 \mu \mathrm{g} / \mathrm{ml})$ showed inhibition (33.59 $\pm 0.55 \%)$ and similar effective as compared to cystone, which showed (61.56 $\pm 0.34 \%)$ inhibition at higher dose $(1500 \mu \mathrm{g} / \mathrm{ml})$ and $(37.93 \pm 0.44 \%)$ inhibition at lower dose $(250 \mu \mathrm{g} / \mathrm{ml})$, while at higher concentration of $\mathrm{NaOx}(10 \mathrm{mM})$, nBFMU showed the $(35.43 \pm 0.17 \%)$ inhibition at higher dose $(1500 \mu \mathrm{g} / \mathrm{ml})$ and $(27.92 \pm 0.16 \%)$ inhibition at lower dose $(250 \mu \mathrm{g} / \mathrm{ml})$, as shown in Table 1 and cystone showed (41.48 $\pm 0.13 \%)$ inhibition at higher dose $(1500 \mu \mathrm{g} / \mathrm{ml})$ and $(25.22 \pm$ $0.04 \%)$ inhibition at lower dose $(250 \mu \mathrm{g} / \mathrm{ml})$, as shown in Table 2. After nucleation formation, another step in urolithiasis is crystal growth. As the oxalate concentration was increased, the crystal formation rate was also increased. In present study, prevention of crystal growth was directly related to the concentration of nBFMU, highest inhibition $(85.49 \pm 0.56 \%)$ was observed at $2000 \mu \mathrm{g} / \mathrm{ml}$. When we have increased the concentration of $\mathrm{NaOx}(2-3.5 \mathrm{mmol} / \mathrm{ml})$ then at same dose level inhibition effect was decreased in nBFMU and cystone as shown in Table 3 and Table 4 respectively. In aggregation assay, Figure 1 and Table 5 showed that crystals were less aggregated in nBFMU treated group with $50.60 \pm 0.24$ inhibition of aggregation at higher dose $1750 \mu \mathrm{g} / \mathrm{ml}$. In CaOX Dissolution assay, after overnight incubation of overnight $\mathrm{CaOx}$ seed were mild-vortexed the weight of $\mathrm{CaOx}$ seed was decreased with increase in the concentration of drug. Figure 2 and Table 6 shows that, $2000 \mu \mathrm{g} / \mathrm{ml}$ of $\mathrm{nBFMU}$ showed $85.10 \% \mathrm{CaOx}$ seeds dissolution as compared to the standard drug cystone which dissolved $69.56 \%$. $\mathrm{IC}_{50}$ of $\mathrm{nBFMU}$ for aggregation and $\mathrm{CaOX}$ dissolution were $1623.53 \mu \mathrm{g} / \mathrm{ml}$ and $400 \mu \mathrm{g} / \mathrm{ml}$ respectively.

\section{Effect on diuresis}

nBFMU has showed a significant diuretic activity at the dose of $800 \mathrm{mg} / \mathrm{kg}(13.01 \pm 0.37 \mathrm{ml} / 100 \mathrm{gm} / 6 \mathrm{hr})$ as compared to normal group $(8.51 \pm 0.26 \mathrm{ml} / 100 \mathrm{gm} / 6 \mathrm{hr})$, furthermore, the effect of nBFMU at dose of $800 \mathrm{mg} / \mathrm{kg}$ was also comparable with the standard diuretic agent, HCT $(14.08 \pm 0.39 \mathrm{ml} / 100 \mathrm{gm} / 6 \mathrm{hr}$ ). (Figure 3)

\begin{tabular}{|c|c|c|c|c|c|}
\hline \multirow{2}{*}{$\begin{array}{l}\text { Conc. of Drug } \\
\qquad(\mu \mathrm{g} / \mathrm{ml})\end{array}$} & \multicolumn{5}{|c|}{$\%$ Inhibition of Nucleation } \\
\hline & $2 \mathrm{mmol} \mathrm{NaOx}$ & $4 \mathrm{mmol} \mathrm{NaOx}$ & $6 \mathrm{mmol} \mathrm{NaOx}$ & $8 \mathrm{mmol} \mathrm{NaOx}$ & $10 \mathrm{mmol} \mathrm{NaOx}$ \\
\hline 250 & $33.59 \pm 0.55$ & $32.01 \pm 0.35$ & $31.41 \pm 0.27$ & $30.60 \pm 0.18$ & $27.92 \pm 0.16$ \\
\hline 500 & $38.31 \pm 0.66$ & $35.06 \pm 0.29$ & $33.18 \pm 0.26$ & $31.88 \pm 0.19$ & $29.22 \pm 0.23$ \\
\hline 750 & $41.63 \pm 0.56$ & $38.32 \pm 0.34$ & $35.10 \pm 0.21$ & $33.76 \pm 0.15$ & $30.70 \pm 0.22$ \\
\hline 1000 & $46.74 \pm 0.64$ & $41.52 \pm 0.23$ & $38.03 \pm 0.25$ & $35.08 \pm 0.18$ & $32.03 \pm 0.13$ \\
\hline 1250 & $52.49 \pm 0.44$ & $43.71 \pm 0.30$ & $39.49 \pm 0.30$ & $36.49 \pm 0.19$ & $33.83 \pm 0.19$ \\
\hline 1500 & $55.43 \pm 0.55$ & $45.31 \pm 0.23$ & $41.06 \pm 0.26$ & $37.47 \pm 0.22$ & $35.43 \pm 0 . .17$ \\
\hline
\end{tabular}

\begin{tabular}{|c|c|c|c|c|c|}
\hline \multirow{2}{*}{$\begin{array}{l}\text { Conc. of Drug } \\
\qquad(\mu \mathrm{g} / \mathrm{ml})\end{array}$} & \multicolumn{5}{|c|}{$\%$ Inhibition of Nucleation } \\
\hline & $2 \mathrm{mmol} \mathrm{NaOx}$ & $4 \mathrm{mmol} \mathrm{NaOx}$ & $6 \mathrm{mmol} \mathrm{NaOx}$ & $8 \mathrm{mmol} \mathrm{NaOx}$ & $10 \mathrm{mmol} \mathrm{NaOx}$ \\
\hline 250 & $37.93 \pm 0.44$ & $35.86 \pm 0.17$ & $32.78 \pm 0.13$ & $29.70 \pm 0.18$ & $25.22 \pm 0.04$ \\
\hline 500 & $43.93 \pm 0.56$ & $42.31 \pm 0.22$ & $39.19 \pm 0.17$ & $34.91 \pm 0.11$ & $30.97 \pm 0.13$ \\
\hline 750 & $50.96 \pm 0.44$ & $47.24 \pm 0.17$ & $43.33 \pm 0.08$ & $39.61 \pm 0.07$ & $34.44 \pm 0.10$ \\
\hline 1000 & $54.79 \pm 0.45$ & $51.96 \pm 0.18$ & $46.82 \pm 0.17$ & $42.18 \pm 0.15$ & $37.86 \pm 0.11$ \\
\hline 1250 & $58.62 \pm 0.40$ & $54.49 \pm 0.23$ & $48.63 \pm 0.19$ & $44.27 \pm 0.11$ & $40.46 \pm 0.13$ \\
\hline 1500 & $61.56 \pm 0.34$ & $56.95 \pm 0.17$ & $50.00 \pm 0.17$ & $45.59 \pm 0.12$ & $41.48 \pm 0.13$ \\
\hline
\end{tabular}


Table 3: Effect of nBFMU on CaOX crystal growth with the increasing amount of $\mathrm{NaOx}$.

\begin{tabular}{|c|c|c|c|c|}
\hline & \multicolumn{4}{|c|}{ \% Inhibition of CaOX crystal growth } \\
\hline Conc. of Drug $(\boldsymbol{\mu} \mathbf{g} / \mathbf{m l})$ & $\mathbf{2 ~} \mathbf{~ m m o l ~ N a O x}$ & $\mathbf{2 . 5} \mathbf{~ m m o l ~ N a O x}$ & $\mathbf{3} \mathbf{~ m m o l ~ N a O x}$ & $\mathbf{3 . 5} \mathbf{~ m m o l ~ N a O x}$ \\
\hline $\mathbf{2 5 0}$ & $62.83 \pm 0.42$ & $57.71 \pm 0.52$ & $34.00 \pm 0.25$ & $37.77 \pm 0.42$ \\
\hline $\mathbf{5 0 0}$ & $65.93 \pm 0.49$ & $60.55 \pm 0.32$ & $37.65 \pm 0.32$ & $39.86 \pm 0.48$ \\
\hline $\mathbf{7 5 0}$ & $69.60 \pm 0.57$ & $63.90 \pm 0.45$ & $39.67 \pm 0.73$ & $42.77 \pm 0.42$ \\
\hline $\mathbf{1 0 0 0}$ & $71.80 \pm 0.49$ & $66.74 \pm 0.39$ & $45.71 \pm 0.45$ & $45.13 \pm 0.30$ \\
\hline $\mathbf{1 2 5 0}$ & $75.22 \pm 0.64$ & $69.72 \pm 0.45$ & $49.66 \pm 0.38$ & $47.84 \pm 0.42$ \\
\hline $\mathbf{1 5 0 0}$ & $79.38 \pm 0.63$ & $72.93 \pm 0.38$ & $53.31 \pm 0.32$ & $50.41 \pm 0.36$ \\
\hline $\mathbf{1 7 5 0}$ & $83.45 \pm 0.57$ & $75.46 \pm 0.45$ & $55.40 \pm 0.33$ & $52.22 \pm 0.30$ \\
\hline $\mathbf{2 0 0 0}$ & $85.49 \pm 0.56$ & $78.59 \pm 0.32$ & $57.41 \pm 0.45$ & $55.76 \pm 0.42$ \\
\hline
\end{tabular}

Table 4: Effect of cystone on CaOX crystal growth with the increasing amount of $\mathrm{NaOx}$.

\begin{tabular}{|c|c|c|c|c|}
\hline \multirow{2}{*}{ Conc. of Drug $(\boldsymbol{\mu g} / \mathbf{m l})$} & \multicolumn{4}{|c|}{ \% Inhibition of CaOX crystal growth } \\
\cline { 2 - 5 } & $\mathbf{2} \mathbf{~ m m o l ~ N a O x}$ & $\mathbf{2 . 5} \mathbf{~ m m o l ~ N a O x}$ & $\mathbf{3} \mathbf{~ m m o l ~ N a O x}$ & $\mathbf{3 . 5} \mathbf{~ m m o l ~ N a O x}$ \\
\hline $\mathbf{2 5 0}$ & $54.93 \pm 0.49$ & $51.15 \pm 0.39$ & $31.76 \pm 0.38$ & $29.09 \pm 0.42$ \\
\hline $\mathbf{5 0 0}$ & $58.92 \pm 0.42$ & $54.21 \pm 0.45$ & $36.53 \pm 0.39$ & $31.18 \pm 0.40$ \\
\hline $\mathbf{7 5 0}$ & $62.83 \pm 0.41$ & $58.16 \pm 0.46$ & $42.35 \pm 0.45$ & $35.13 \pm 0.41$ \\
\hline $\mathbf{1 0 0 0}$ & $67.23 \pm 0.40$ & $60.85 \pm 0.51$ & $45.11 \pm 0.45$ & $38.26 \pm 0.48$ \\
\hline $\mathbf{1 2 5 0}$ & $69.43 \pm 0.56$ & $65.02 \pm 0.32$ & $49.14 \pm 0.58$ & $41.11 \pm 0.30$ \\
\hline $\mathbf{1 5 0 0}$ & $73.10 \pm 0.42$ & $68.45 \pm 0.22$ & $51.60 \pm 0.53$ & $44.23 \pm 0.60$ \\
\hline $\mathbf{1 7 5 0}$ & $77.09 \pm 0.49$ & $72.85 \pm 0.39$ & $54.51 \pm 0.45$ & $46.73 \pm 0.25$ \\
\hline $\mathbf{2 0 0 0}$ & $80.92 \pm 0.42$ & $74.34 \pm 0.40$ & $58.61 \pm 0.38$ & $51.25 \pm 0.43$ \\
\hline
\end{tabular}

\section{CaOx Aggregation of nBFMU}

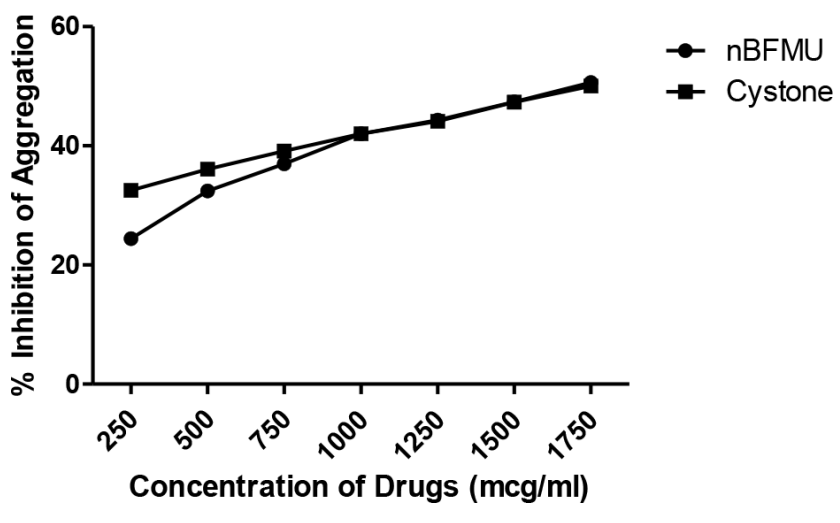

Figure 1: Effect of nBFMU on in vitro CaOx crystal aggregation.

\begin{tabular}{|c|c|c|}
\hline \multirow{2}{*}{$\begin{array}{l}\text { Conc. of Drug } \\
\qquad(\mu \mathrm{g} / \mathrm{ml})\end{array}$} & \multicolumn{2}{|c|}{$\%$ Inhibition of crystal aggregation } \\
\hline & nBFMU & Cystone \\
\hline 250 & $24.42 \pm 0.28$ & $32.51 \pm 0.14$ \\
\hline 500 & $32.40 \pm 0.23$ & $36.06 \pm 0.25$ \\
\hline 750 & $36.99 \pm 0.24$ & $39.12 \pm 0.19$ \\
\hline 1000 & $42.02 \pm 0.23$ & $42.02 \pm 0.23$ \\
\hline 1250 & $44.32 \pm 0.38$ & $44.10 \pm 0.19$ \\
\hline 1500 & $47.37 \pm 0.18$ & $47.32 \pm 0.23$ \\
\hline 1750 & $50.60 \pm 0.24$ & $50.00 \pm 0.19$ \\
\hline
\end{tabular}

\section{CaOx Dissolution of nBFMU}

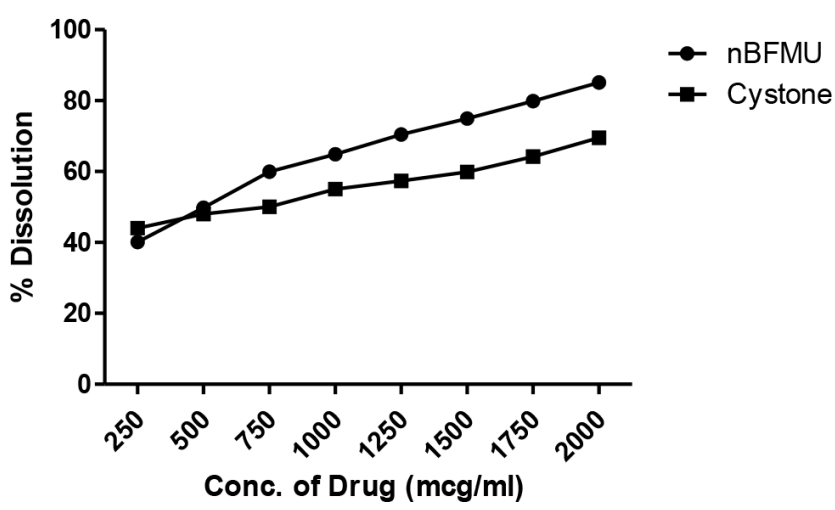

Figure 2: Effect of nBFMU on in vitro CaOx crystal dissolution.

\section{Effect on various parameter of NaOX model}

Effect on relative body and organ weight, urine volume, urinary $\mathrm{pH}$ and crystalluria

Administration of $\mathrm{NaOX}(70 \mathrm{mg} / \mathrm{kg}$, i.p) for 7 days caused significant $(\phi<0.001)$ reduction in relative body weight and increased relative organ weight in disease group as compared to the normal group. While simultaneous treatment with nBFMU (400 and $800 \mathrm{mg} / \mathrm{kg}$ ) and cystone $(750 \mathrm{mg} / \mathrm{kg}$, std drug) significantly $(\not<0.001)$ increased the relative body weight and decreased the 


\section{Table 6: Effect of nBFMU and cystone on crystal dissolution.}

\begin{tabular}{|c|c|c|}
\hline \multirow{2}{*}{$\begin{array}{c}\text { Conc. of Drug }(\boldsymbol{\mu g} / \\
\mathbf{m l})\end{array}$} & \multicolumn{2}{|c|}{$\%$ Dissolution of CaOx crystals } \\
\cline { 2 - 3 } & nBFMU & Cystone \\
\hline $\mathbf{2 5 0}$ & $40.10 \pm 0.78$ & $44.00 \pm 0.76$ \\
\hline $\mathbf{5 0 0}$ & $49.83 \pm 0.61$ & $48.00 \pm 0.28$ \\
\hline $\mathbf{7 5 0}$ & $59.96 \pm 0.49$ & $50.00 \pm 0.29$ \\
\hline $\mathbf{1 0 0 0}$ & $64.83 \pm 0.72$ & $55.00 \pm 0.86$ \\
\hline $\mathbf{1 2 5 0}$ & $70.44 \pm 0.47$ & $57.40 \pm 0.49$ \\
\hline $\mathbf{1 5 0 0}$ & $74.96 \pm 0.66$ & $59.86 \pm 0.41$ \\
\hline $\mathbf{1 7 5 0}$ & $79.83 \pm 0.44$ & $64.23 \pm 0.43$ \\
\hline $\mathbf{2 0 0 0}$ & $85.10 \pm 0.78$ & $69.56 \pm 1.09$ \\
\hline
\end{tabular}

\section{Diuretic activity of nBFMU}

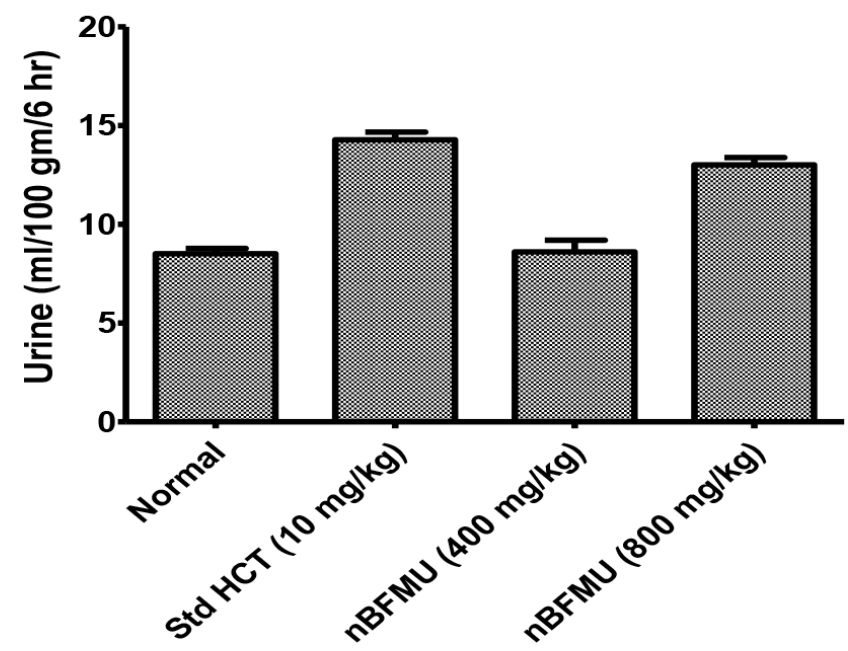

Figure 3: Diuretic effect of nBFMU in rats.

relative organ weight as compared to the control group. Significant $(\phi<0.001)$ decreased in volume of urine $(\mathrm{ml} / 24 \mathrm{hr})$ was observed in disease control group as compared to normal group, while nBFMU (400 and $800 \mathrm{mg} / \mathrm{kg}$ ) and cystone $(750 \mathrm{mg} / \mathrm{kg}$, std drug) showed significant $(p<0.001)$ improvement in output of urine as compared to disease control group. Furthermore, significant $(p<0.001)$ decrease in urinary $p H$ was observed in disease control group, which was significantly $(p<$ 0.001) increased in nBFMU (400 and $800 \mathrm{mg} / \mathrm{kg}$ ) and cystone $(750 \mathrm{mg} / \mathrm{kg}$, std drug) group. The data are listed in Table 7. In crystalluria study of urine, $\mathrm{CaOX}$ crystals were absent in normal group animals (Figure 4(a)), whereas large size and more number of crystals were observed in disease control group animal urine. (Figure 4(b)). In nBFMU and cystone treated animals urine were showed very less number and small size of $\mathrm{CaOX}$ crystals. (Figure 4(d) and 4(e) and 4(c)).

\section{Effect on urinary parameter}

Administration of $\mathrm{NaOX}(70 \mathrm{mg} / \mathrm{kg}$, i.p) for 7 days to Wistar rats resulted in hyperoxyluria. Due to that excretion of various urolithiatic promoters in urine such as oxalate, calcium, urea, uric acid and phosphate levels were significantly $(p<0.001)$ increased in the urine of disease control group and various urolithiatic
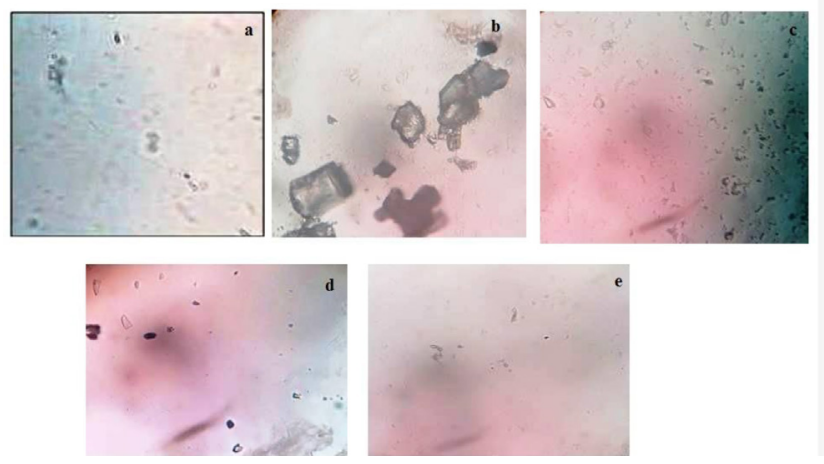

Figure 4: CaOX crystal observed under microscope in $24 \mathrm{hr}$ urine of rat. (a) Normal control group showed absence of crystal (b) Disease control group showed large crystal and (c) Standard group (cystone $750 \mathrm{mg} / \mathrm{kg}$ ) (d) Treatment group I (400 mg/kg) and (e) Treatment group II (800 mg/kg) showed less number of crystals in urine

\begin{tabular}{|c|c|c|c|c|c|}
\hline \multicolumn{7}{|c|}{ Table 7: Effect of nBFMU on body weight and organ weight, urine volume, urinary pH in } \\
NaOX induced urolithiasis. \\
\hline & $\begin{array}{c}\text { Group I } \\
\text { (Normal } \\
\text { control) }\end{array}$ & $\begin{array}{c}\text { Group II } \\
\text { (Disease } \\
\text { control) }\end{array}$ & $\begin{array}{c}\text { Group II } \\
\text { (Standard } \\
\text { control) }\end{array}$ & $\begin{array}{c}\text { Group 1V } \\
\text { (Treatment } \\
\text { Group I) }\end{array}$ & $\begin{array}{c}\text { Group V } \\
\text { (Treatment } \\
\text { Group II) }\end{array}$ \\
\hline Body weight (\%) & $101.4 \pm 0.3$ & $96.16 \pm 0.51^{\mathrm{a}^{*}}$ & $100.7 \pm 0.14^{\mathrm{b}^{*}}$ & $103.6 \pm 0.38^{\mathrm{b}^{*}}$ & $102.5 \pm 0.37^{\mathrm{b}^{*}}$ \\
\hline Relative organ weight (\%) & $0.49 \pm 0.03$ & $0.61 \pm 0.03^{\mathrm{a}^{*}}$ & $0.52 \pm 0.01^{\mathrm{bt}}$ & $0.52 \pm 0.02^{\mathrm{b}^{*}}$ & $0.51 \pm 0.01^{\mathrm{b}^{*}}$ \\
\hline Urine Volume (ml/24 hr) & $8.12 \pm 0.42$ & $4.37 \pm 0.24^{\mathrm{a}^{*}}$ & $11.00 \pm 0.21^{\mathrm{b}^{*}}$ & $11.55 \pm 0.33^{\mathrm{b}^{*}}$ & $14.13 \pm 0.23^{\mathrm{b}^{*}}$ \\
\hline Urinary pH & $6.76 \pm 0.04$ & $5.32 \pm 0.04^{\mathrm{a}^{*}}$ & $6.45 \pm 0.02^{\mathrm{b}^{*}}$ & $5.82 \pm 0.06^{\mathrm{b}^{*}}$ & $6.37 \pm 0.06^{\mathrm{b}^{*}}$ \\
\hline
\end{tabular}

All values are expressed in mean $\pm \operatorname{SEM}(n=6)$, one-way ANOVA followed by Dunnett's test.

* $p<0: 001$ statistically significant

$\# p<0: 005$ statistically significant

a compared with normal Group

b compared with disease control group 
inhibitors like citrate and magnesium level was found significantly $(\not<0.001)$ decreased in the urine and due to renal function impairment, decreased in creatinine clearance in urine of disease control group as compared to normal group. However, supplementation with nBFMU (400 and $800 \mathrm{mg} / \mathrm{kg}$ ) showed a significant $(p<0.001)$ reduction in urolithiatic promoter and significantly increased urolithiatic inhibitors and creatinine clearance level as compared to the disease control group. Furthermore, treatment groups results were also comparable with the Cystone $(750 \mathrm{mg} / \mathrm{kg})$ treated group. The data are listed in Table 8.

\section{Effect on serum parameter}

Induction of $\mathrm{CaOX}$ stone in renal cause function impairment in renal, resulting in increased glomerular and tubular markers in serum. In the current study, serum calcium, phosphorus, uric acid and urea levels were increased and magnesium level was decreased significantly $(p<0.001)$ in diseased control group when compared with normal group. While simultaneous treatment with nBFMU (400 and $800 \mathrm{mg} / \mathrm{kg}$ ) showed significantly $(p<0.001)$ decreased calcium, phosphorus, uric acid and urea level where magnesium level was increased when compared to disease control group. Treatment groups results was similar to the standard group (Cystone, $750 \mathrm{mg} / \mathrm{kg}$ ). The data are listed in Table 8.

\section{Effect on Kidney homogenate parameter}

Urolithiatic promoters like oxalate, calcium, phosphate and uric acid level were significantly $(p<0.001)$ increased in kidney of disease control group as

\begin{tabular}{|c|c|c|c|c|c|}
\hline & $\begin{array}{c}\text { Group I } \\
\text { (Normal Control) }\end{array}$ & $\begin{array}{c}\text { Group II } \\
\text { (Model Control) }\end{array}$ & $\begin{array}{l}\text { Group II } \\
\text { (Standard } \\
\text { Control) }\end{array}$ & $\begin{array}{l}\text { Group 1V } \\
\text { (Treatment } \\
\text { Group I) }\end{array}$ & $\begin{array}{c}\text { Group V } \\
\text { (Treatment } \\
\text { Group II) }\end{array}$ \\
\hline \multicolumn{6}{|c|}{ Urine Parameter (mg/24 hr) } \\
\hline Calcium & $2.85 \pm 0.19$ & $4.8 \pm 0.26^{\mathrm{a}^{*}}$ & $3.18 \pm 0.10^{b^{*}}$ & $3.46 \pm 0.13^{b^{*}}$ & $2.95 \pm 0.07^{b^{*}}$ \\
\hline Oxalate & $4.14 \pm 0.17$ & $10.15 \pm 0.05^{\mathrm{a}^{*}}$ & $6.80 \pm 0.08^{b^{*}}$ & $7.14 \pm 0.06^{b^{*}}$ & $5.23 \pm 0.23^{\mathrm{b}^{*}}$ \\
\hline Phosphate & $4.22 \pm 0.11$ & $6.95 \pm 0.27 \mathrm{a}^{\mathrm{a}^{*}}$ & $5.60 \pm 0.19^{b^{*}}$ & $5.60 \pm 0.15^{\mathrm{b}^{*}}$ & $4.82 \pm 0.04^{b^{*}}$ \\
\hline Uric acid & $1.93 \pm 0.06$ & $3.89 \pm 0.07^{\mathrm{a}^{*}}$ & $2.16 \pm 0.06^{\mathrm{b}^{*}}$ & $2.31 \pm 0.21^{\mathrm{b}^{*}}$ & $2.01 \pm 0.01^{b^{*}}$ \\
\hline Urea & $0.58 \pm 0.03$ & $1.36 \pm 0.08^{a^{*}}$ & $0.80 \pm 0.05^{\mathrm{b}^{*}}$ & $0.86 \pm 0.38^{b^{*}}$ & $0.70 \pm 0.03^{\mathrm{b}^{*}}$ \\
\hline Citrate & $21.25 \pm 0.92$ & $7.99 \pm 0.08^{\mathrm{a}^{*}}$ & $18.46 \pm 0.18^{b^{*}}$ & $12.91 \pm 0.18^{\mathrm{b} \#}$ & $17.32 \pm 0.20^{b^{*}}$ \\
\hline Magnesium & $3.10 \pm 0.26$ & $1.07 \pm 0.07 \mathrm{a}^{\mathrm{a}^{*}}$ & $2.83 \pm 0.11^{b^{*}}$ & $1.53 \pm 0.04^{\mathrm{b} \#}$ & $2.31 \pm 0.06^{b^{*}}$ \\
\hline Creatinine Clearance & $36.17 \pm 1.51$ & $10.00 \pm 2.05^{\mathrm{a}^{*}}$ & $44.61 \pm 2.01^{b^{*}}$ & $63.55 \pm 3.62^{\mathrm{b}^{*}}$ & $75.16 \pm 5.25^{b^{*}}$ \\
\hline \multicolumn{6}{|c|}{ Serum Parameter (mg/dl) } \\
\hline Calcium & $9.71 \pm 0.19$ & $12.26 \pm 0.16^{\mathrm{a}^{*}}$ & $9.97 \pm 0.19^{b^{*}}$ & $10.77 \pm 0.19^{\mathrm{b} \#}$ & $10.12 \pm 0.25^{b^{*}}$ \\
\hline Phosphate & $4.63 \pm 0.51$ & $7.90 \pm 0.23^{a^{*}}$ & $5.33 \pm 0.32^{b^{*}}$ & $5.49 \pm 0.15^{\mathrm{b} \#}$ & $4.85 \pm 0.19^{b^{*}}$ \\
\hline Uric acid & $3.68 \pm 0.40$ & $6.28 \pm 0.18^{\mathrm{a}^{*}}$ & $4.23 \pm 0.25^{b^{*}}$ & $3.75 \pm 0.32^{b^{*}}$ & $3.05 \pm 0.22^{b^{*}}$ \\
\hline Urea & $12.50 \pm 1.03$ & $27.68 \pm 0.89 \mathrm{a}^{*}$ & $15.18 \pm 0.89^{b^{*}}$ & $22.32 \pm 0.89^{\mathrm{b} \#}$ & $12.50 \pm 1.03^{b^{*}}$ \\
\hline Magnesium & $3.30 \pm 0.11$ & $1.82 \pm 0.08^{a^{*}}$ & $2.83 \pm 0.11^{b^{*}}$ & $2.43 \pm 0.06^{\mathrm{bH}}$ & $3.09 \pm 0.05^{b^{*}}$ \\
\hline \multicolumn{6}{|c|}{ Kidney Homogenate Parameter } \\
\hline Calcium (mg/gm tissue) & $4.92 \pm 0.08$ & $8.14 \pm 0.11^{\mathrm{a}^{*}}$ & $6.03 \pm 0.07^{b^{*}}$ & $5.68 \pm 0.12^{b^{*}}$ & $5.1 \pm 0.11^{\mathrm{b}^{*}}$ \\
\hline Oxalate (mg/gm tissue) & $1.39 \pm 0.09$ & $5.91 \pm 0.16^{\mathrm{a}^{*}}$ & $2.41 \pm 0.31^{b^{*}}$ & $2.49 \pm 0.12^{b^{*}}$ & $2.15 \pm 0.12^{b^{*}}$ \\
\hline Uric acid (mg/gm tissue) & $2.23 \pm 0.17$ & $3.90 \pm 0.23^{a^{*}}$ & $2.59 \pm 0.10^{b^{*}}$ & $3.61 \pm 0.01^{\mathrm{bH}}$ & $3.14 \pm 0.03^{b^{*}}$ \\
\hline Phosphate (mg/gm tissue) & $2.95 \pm 0.23$ & $5.14 \pm 0.31 \mathrm{a}^{*}$ & $3.41 \pm 0.13^{b^{*}}$ & $3.79 \pm 0.16^{\mathrm{b} \#}$ & $3.05 \pm 0.15^{b^{*}}$ \\
\hline $\begin{array}{l}\text { Catalase (nmoles of } \mathrm{H}_{2} \mathrm{O}_{2} \\
\text { utilized } / \mathrm{min} / \mathrm{mg} \text { Protein) }\end{array}$ & $1.69 \pm 0.05$ & $0.72 \pm 0.05^{\mathrm{a}^{*}}$ & $1.39 \pm 0.11^{b^{*}}$ & $1.29 \pm 0.05^{\mathrm{b \#}}$ & $1.49 \pm 0.05^{\mathrm{b}^{*}}$ \\
\hline
\end{tabular}

All values are expressed in mean \pm SEM $(n=6)$, one-way ANOVA followed by Dunnett's test.

$* p<0: 001$ statistically significant

$\# p<0: 005$ statistically significant

a compared with normal Group

b compared with disease control group 


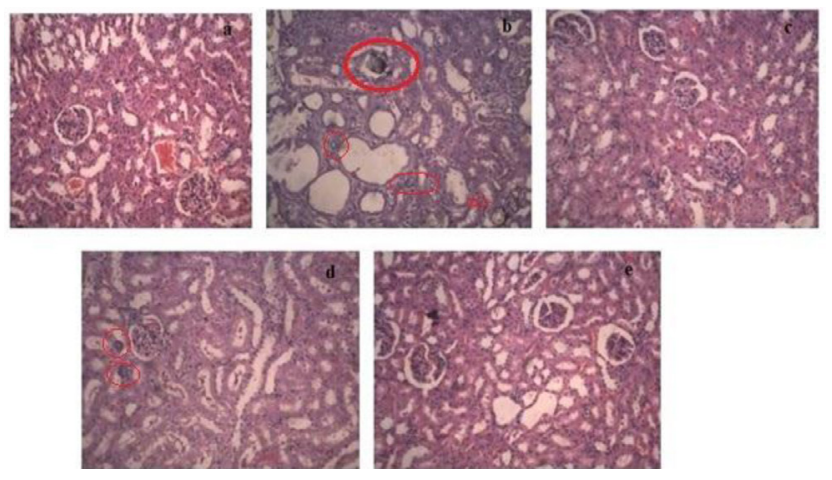

Figure 5: Histology of rat kidney. (a) Normal group (b) Disease control group showed crystal deposition having large size (c) standard group (cystone $750 \mathrm{mg} / \mathrm{kg}$ ) (d) Treatment group I (400 mg/kg) and (e) Treatment group II ( $800 \mathrm{mg} / \mathrm{kg})$ showed less number of crystal and normal structure of kidney.

compared to normal group. However, those promoters were found to be significantly $(p<0.001)$ decreased in the kidney of treatment groups as compared to the disease control group in dose depended manner. $\mathrm{NaOX}$ administration significantly decreased the activity of antioxidant enzyme catalase $(p<0.001)$ in disease control group while in treatment groups significant increase in catalase enzyme activity; provided protection against oxidative changes in the tissue. The data are listed in Table 8.

\section{Effect on Histopathology of Kidney}

In normal group, kidney section showed normal architecture of the kidney (Figure 5(a)), while in disease control group due to administration of $\mathrm{NaOX}$ agent caused severe damage to the glomeruli, tubules, medulla and interstitial spaces. The presence of $\mathrm{CaOX}$ crystals in intratubular space also seen (Figure 5(b)) in disease control group kidney section while in treatment groups sections major damage was recovered and less crystal deposition in intratubular space. (Figure 5(d) and 5(e)). In standard group section crystal deposition was not observed and renal damage was found recovered. (Figure 5(c)).

\section{DISCUSSION}

Renal stone formation is a biological process that involves a physicochemical element and crystallisation. An important factor in crystallization is nucleation that leads to crystal growth and crystal aggregation which are responsible for stone formation. Agents that cause inhibition of crystallization and modifiers of these process or decreased oxalate supersaturation are major interest agents for urolithiasis treatment. Various inhibitors can affect crystal nucleation, growth or aggregation. ${ }^{28}$ In present study, in vitro assay were designed to address the key elements like nucleation, crystal growth and aggregation of the crystal. Nucleation is a first step for the initiation of crystals formation; Park et al..$^{29}$ reported that severity of stone formation is directly proportional to level of urinary oxalate, as supersaturation levels of ions increase spontaneously crystallize the particles and increased the nucleation formation. As increased in oxalate concentration, nucleation rate was increased. nBFMU inhibited the stone formation by inhibiting the nucleation of $\mathrm{CaOX}$ in solution in dose depended manner with respect to the concentration of $\mathrm{NaOX}$. This activity of nBFMU could be its ability to complex with oxalate and calcium ions in solution and decrease supersaturation level. After nucleation, free calcium and oxalate particles which present in fluid, attached to the preformed $\mathrm{CaOX}$ crystal and increase in the crystal size. Crystal growth was dependent on the concentration level of oxalate and calcium. Present study showed that nBFMU prevent the crystal growth in dose depended manner, but inhibition rate was found decreased at the same dose of extract with the gradually increase in $\mathrm{NaOX}$ concentration. Small crystals were easily excreted in urine but numerous crystals come together and adhere to form large crystal which usually retain in renal tubules and promoting the stone formation. Therefore, the crystal aggregation process is thought be a fundamental step in the renal stone development. nBFMU inhibited the in vitro $\mathrm{CaOX}$ aggregation in concentration depended manner. Some findings suggested that chemical treatments may be a useful for improving the efficacy of stone treatment via dissolving larger or harder stones. Zhou et al. ${ }^{30}$ reported that buffered EDTA solvents may be feasible chemical treatment modalities for improving the efficacy of $\mathrm{CaOx}$ stone dissolution. In present study, nBFMU was found active in dissolving the $\mathrm{CaOX}$ stones in concentration depended manner, which indicate that nBFMU contain some of the components that constitutes to increase the $\mathrm{CaOX}$ stone dissolution. Qualitative phytochemical estimation of nBFMU revealed the presence of flavonoids, saponins and phenolic compounds. These phytoconstituents are of ulmost significance for inhibiting kidney stone formation. Saponins possess antilithic properties and are known to disintegrate mucoproteins that are crucial components of stone matrix. ${ }^{31}$ Rutin, quercetin, hyperoside and diosmin are known as flavonoids with high antioxidant and anti-lithiatic activities. ${ }^{32} \mathrm{nBFMU}$ contains $7.52 \pm 0.40 \mathrm{mg}$ quercetin equivalents $/ \mathrm{g}$ flavonoids and $30.32 \pm 0.62 \mathrm{mg}$ diosgenin equivalent saponin/g. Therefore, the prevention of nucleation, 
crystal growth, crystal aggregationl and crystal dissolving property of nBFMU.

In the in vivo animal model, male rats were selected for the induction study because the urinary system of male rates resembles to that of human ${ }^{33}$ and earlier studies have also showed that the amount of stone deposition in male rats was significantly higher as compared to the female rats. ${ }^{34}$ Lee et al. ${ }^{35}$ and Iguchi et al. ${ }^{36}$ have also reported that sex hormone of female has inhibitory effect on renal stone formation in rats. Stones formed in kidneys of rats and humans are identical at the ultra-structural level in nature and composition of their matrix, thus rat models of urolithiasis are helpful experimental tools for exploring the pathphysiology and management of disease. Spontaneous formation of $\mathrm{CaOX}$ is very rare in rats, Thus the renal stone is experimentally induced and rats are made hyperoxaluric either by exposure to the toxin ethylene glycol, or by administration of excessive amount of oxalate, or by doing various nutritional manipulations in rat food. ${ }^{37}$ Stones with smaller size can easily travel through the urinary system, but larger size stones may lead to the obstruction and pain in renal capillary tube. This could also result in decrease the food consumption. Due to that decrease in the body weight and increased the weight of kidney due to deposition of stone. Present study also revealed a similar pattern with significant reduction in relative body weight and increased the relative organ weight in disease control group. In nBFMU treated rats body weight and organ weights were similar to the normal group animals, that indicate that nBFMU might be prevent the pain.

Many studies showed that administration of $\mathrm{NaOX}$ in animals induced the stone formation which caused by hyperoxaluria and subsequent hypercalciuria, which further lead to the increased retention and excretion of oxalate. $^{38}$ An increased urinary levels of calcium and oxalate favors the nucleation process and precipitated $\mathrm{CaOX}$ attached to renal tubules and create more nucleation centres for new $\mathrm{CaOX}$ crystals. Decreased excretion of calcium level from $4.8 \pm 0.26$ to $2.95 \pm 0.07 \mathrm{mg} / 24 \mathrm{hr}$ and oxalate level from $10.15 \pm 0.05$ to $5.23 \pm 0.23 \mathrm{mg} / 24 \mathrm{hr}$ upon treatment with $\mathrm{nBFMU}(800 \mathrm{mg} / \mathrm{kg})$ indicate that nBFMU might be reducing the supersaturation of oxalate and calcium ions in urine and preventing stone formation or growth in kidney.

Urinary $\mathrm{pH}$ is the important factor in formation of stone in kidney. At low urinary $\mathrm{pH}$ solubility of $\mathrm{CaOX}$ stone decrease and promote the $\mathrm{CaOX}$ stone formation. In present study urinary $\mathrm{pH}$ of disease control group was $5.32 \pm 0.04$, which indicates that $\mathrm{CaOX}$ solubility is minimum and hence urine get supersaturated with oxalate and calcium ions, start the stone formation. nBFMU treated rats showed that significant increase in urinary $\mathrm{pH}(6.37 \pm 0.06, p<0.001)$, which indicate that nBFMU increase the solubility of $\mathrm{CaOX}$ stone and decrease the supersaturation level of ions in urine.

Decrease in the urine volume increases the saturation level of oxalate and start the events of $\mathrm{CaOX}$ crystal formation. In nBFMU treated rats urine volume was found significantly increased $(14.13 \pm 0.23 \mathrm{mg} / 24 \mathrm{hr}$, $p<0.001)$ as compared to disease control group $(4.37 \pm 0.24 \mathrm{mg} / 24 \mathrm{hr})$ which decreased the saturation level of ions like oxalate, calcium and prevents the crystal formation. Diuresis effect of nBFMU could be reponsible for fluse out the excessive amount of ions and helped in mechanical expulsion of stone.

Increased excretion of uric acid and inorganic phosphate has been reported in stone formers and also observed in hyperoxaluric rats. High levels of urinary phosphate along with oxalate provides an appropriate environment for formation of calcium phosphate crystals, which further induces $\mathrm{CaOX}$ deposition in renal and may be responsible for aggregation of $\mathrm{CaOX} \cdot{ }^{34}$ Uric acid which interferes $\mathrm{CaOX}$ solubility, induces the heterogeneous nucleation of $\mathrm{CaOX}$ stone and reduces the natural inhibitory activity of glycosaminoglycans in urine. ${ }^{39}$ Glycosaminoglycans blocks the growth site of crystals and preventing or delayed the further development of crystal growth and aggregation. ${ }^{40}$ There was significant increase in excretion of inorganic phosphate (6.95 \pm $0.27 \mathrm{mg} / 24 \mathrm{hr}$ ) and uric acid (3.89 $\pm 0.07 \mathrm{mg} / 24 \mathrm{hr})$ in urine in the disease control group than normal group (4.22 \pm 0.11 and $1.93 \pm 0.06 \mathrm{mg} / 24 \mathrm{hr}$ respectively), that level was significantly decreased in nBFMU treated groups (4.82 \pm 0.04 and $2.01 \pm 0.01 \mathrm{mg} / 24 \mathrm{hr}$ respectively, $p<0.001$ ), which indicate that nBFMU may prevent the deposition of crystal in renal by preventing calcium phosphate crystals formation and increasing the solubility of $\mathrm{CaOX}$ crystals and increased the activity of glycosaminoglycans in the kidney.

Magnesium is considered as urolithiatic inhibitor. It makes complexes with oxalate as well as calcium and reduces the supersaturation of $\mathrm{CaOX}$ and as a consequence, the $\mathrm{CaOX}$ crystals growth and rate of nucleation were also reduced. ${ }^{41}$ In disease control group levels of magnesium was decreased $(1.07 \pm 0.07 \mathrm{mg} / 24 \mathrm{hr}$, $p<0.001)$ but in standard group and nBFMU treated groups magnesium level was increased $(2.83 \pm 0.11$ and $2.31 \pm 0.06 \mathrm{mg} / 24 \mathrm{hr}$ respectively, $p<0.001$ ) in urinary samples as compared to disease control group. It indicates that nBFMU increased level of magnesium which makes complexes with oxalate as well as calcium and 
reduced the supersaturation of $\mathrm{CaOX}$ and prevent the crystallization.

Hypocitraturia is the metabolic abnormality in renal stones patients. Citrate has stone inhibiting action in urine. ${ }^{34}$ Citrate binds with the calcium in urine to form a soluble complex and this increases the urine $\mathrm{pH} .{ }^{42}$ Low urinary $\mathrm{pH}$ favored $\mathrm{CaOX}$ stone formation. In present study, it was found that, nBFMU treatment significantly increased $(17.32 \pm 0.20 \mathrm{mg} / 24 \mathrm{hr}, p<0.001)$ the level of citrate as compared to disease control group $(7.99 \pm 0.08 \mathrm{mg} / 24 \mathrm{hr})$ and prevented the risk of stone formation.

In renal stone patients there was decreased in urinary output due to decreases glomerular filtration rate, this leads to the accumulation of waste products in the blood like nitrogenous substance such as urea, creatinine and decrease in creatinine clearance. ${ }^{43}$ The administration of nBFMU significantly lowered the serum urea (12.50 \pm $1.03 \mathrm{mg} / \mathrm{dl}, p<0.001)$ and enhanced creatinine clearance $(75.16 \pm 5.25 \mathrm{mg} / \mathrm{dl}, p<0.001)$ as compared to disease control group $(27.68 \pm 0.89$ and $10.00 \pm 2.05 \mathrm{mg} / \mathrm{dl}$, respectively). This effect can be attribute due to diuresis effect of nBFMU.

Histopathology of kidney in calculi induced rats showed irregular shaped crystal of $\mathrm{CaOX}$ were deposition inside the tubules which caused the proximal renal tubules dilation along with interstitial inflammation that might be attributed due to excessive amount of oxalate in kidney. Oxalate is the precursor molecule for lipid peroxidation, which reacts with polyunsaturated fatty acids in the cell membrane and damage the renal tissue. ${ }^{44}$ Co-treatment with nBFMU decreased the size and number of $\mathrm{CaOX}$ crystal deposition in renal tubules and also prevented damages in the calyxes and tubules.

Such rapid and acute diuretic activity of nBFMU may be due to presence of active phytochemicals such as flavonoids, steroids, terpenoids and phenolic compound. Diuretic action is a main part in treatment of renal stone patients, as an increase in the urine volume in urinary system will help to dissolve the $\mathrm{CaOX}$ stones and prevent the further retention in renal tissues and flush out the deposits crystals. The lithotriptic effect of nBFMU may be due to presence of saponin and flavonoids which identified by phytoconstituents analysis in the present study. Earlier studies reported that saponin rich plants play very essential role in prevention of stone formation in kidney against agents induced urolithiasis in rats. ${ }^{45}$

\section{CONCLUSION}

On the basis of above results and discussion, it can be concluded that, nBFMU has antiurolithiatic activity in $\mathrm{NaOX}$ induced urolithiasis by promoting various urolithiatic inhibitors like magnesium and citrate and suppressing various urolithiatic promoters like calcium, oxalate, phosphate in $24 \mathrm{hr}$ urine, serum and renal tissue. In addition, diuretic activity of nBFMU helps to flush out stone promoters in urine and decreased supersaturation level of ions in urine and this prevents new $\mathrm{CaOX}$ nuclei formation. Diuretic activity also smooths the surface of $\mathrm{CaOX}$ due to that decrease in renal tissue damage and also increased the $\mathrm{CaOX}$ stone dissolution. Thus, the current result highlight that the seeds of M. uniflorum have potential and beneficial effect in the prevention of $\mathrm{CaOX}$ stone formation in kidney. But, for find out to effective chemical constituents and detail mechanism(s) of that component of nBFMU, further studies are necessary.

\section{ACKNOWLEDGEMENT}

The authors thank to the Institute of Pharmacy, Nirma University for providing the infrastructure and technical facilities to accomplish the research. This study is a part of the research work of Mr. Vaibhavkumar B. Patel carried out at the Institute of Pharmacy, Nirma University and to be submitted to the Institute as a part of the Ph.D. work.

\section{CONFLICT OF INTEREST}

The authors declare no conflicts of interest.

\section{ABBREVIATIONS}

BUN: Blood urea nitrogen; CaOX: Calcium oxalate; HCT: Hydrochlorothiazide; NaCl: Sodium chloride; NaOX: Sodium oxalate; nBFMU: n-butanol fraction of $M$. uniflorum; LDH: Lactase dehydrogenase; ROS: Reactive oxygen species.

\section{REFERENCES}

1. Scales CD, Smith AC, Hanley JM, Saigal CS. Prevalence of kidney stones in the United States. Euro Urol. 2012;62(1):160-5.

2. Alelign T, Petros B. Kidney stone disease: An update on current concepts. Adv Urol. 2018;1:1-12.

3. Sohgaura A, Bigoniya P. A review on epidemiology and etiology of renal stone. Am J Drug Discov Dev. 2017;7(2):54-62.

4. Nabi G, Downey P, Keeley FX, Watson GM, McClinton S. Extracorporeal shock wave lithotripsy (ESWL) versus ureteroscopic management for ureteric calculi. Cochrane Database Syst Rev. 2012;5:1095-103.

5. Aeckart KSJ, Schroder FH. Effect of extra corporeal shock wave lithotripsy (ESWL) on renal tissue. Urol Res. 1989;17(1):3-7. 
6. Kieley S, Dwivedi R, Monga M. Ayurvedic medicine and renal calculi. J Endourol. 2008;22(8):1613-6.

7. Zeven AC, De W. Dictionary of cultivated plants and their regions of diversity. Wageningen: Centre for Agricultural Publication and Documentation. 1982;1-263.

8. Pande PC. Kumaon mein prachalit per-paudhon ke sthaniya namo kivyautpatti. Ethnobotany of Kumaon Himalaya. 1993;253-62.

9. Pati CK, Bhattacharjee A. Seed potentiation of a horse-gram cultivar by herbal manipulation. Int J of Medi Plants Res. 2013;2(1):152-5.

10. Bravo L, Siddhuraju P, Saura-Calixto F. Composition of underexploited Indian pulses comparison with common legumes. Food Chem. 1999;64(2):185-92.

11. Ghani A. Medicinal plants of Bangladesh: Chemical constitutents and uses. Asiatic Society of Bangladesh, Dhaka. 1998;460.

12. Yadava ND, Vyas NL. Horsegram. In: Arid legumes. Agro botanical publishers, India. 1994;64-57.

13. Perumal S, Sellamuthu M. The antioxidant activity and free radical scavenging capacity of dietary phenolic extracts from horse gram (Macrotyloma uniflorum (lam.) verdc.) seeds. Food Chem. 2007;105(3):950-8.

14. Shastri S. Shri aryabhishak. Bhikshu akhandanand $6^{\text {th }}$ edition. 1982;138.

15. Sreerama YN, Neelam DA, Sashikala VB, Pratape VM. Distribution of nutrients and antinutrients in milled fractions of chickpea and horse gram: Seed coat phenolics and their distinct modes of enzyme inhibition. J Agri Food Chem. 2010;58(7):4322-30.

16. Ghodasara J, Pawar A, Deshmukh C, Kuchekar B. Inhibitory effect of rutin and curcumin on experimentally-induced calcium oxalate urolithiasis in rats. Pharmacognosy Res. 2010;2(6):388-92.

17. Zhu W, Xu YF, Feng Y, Peng B, Che JP, Liu M, et al. Prophylactic effects of quercetin and hyperoside in a calcium oxalate stone forming rat model. Urolithiasis. 2014;42(6):519-26.

18. Marinova D, Ribarova F, Atanassova M. Total phenolics and flavonoids in Bulgarian fruits and vegetables. J of the University of Chemi Technology and Metallurgy. 2005;40(3):255-60.

19. Obadoni B, Ochuko P. Phytochemical studies and comparative efficacy of the crude extracts of some haemostatic plants in edo and delta states of Nigeria. Global J of Pure and Applied Sci. 2002;8(2):203-8.

20. Hennequin C, Lalanne V, Daudon M, Lacour B, Drueke T. A new approach to studying inhibitors of calcium oxalate crystal growth. Urol Res. 1993;21(2):101-8.

21. Atmani $F$, Khan S. Effects of an extract from Herniaria hirsuta on calcium oxalate crystallization in vitro. BJU Int. 2000;85(6):621-5.

22. Chaudhary A, Singla S, Tandon C. In vitro evaluation of Terminalia arjuna on calcium phosphate and calcium oxalate crystallization. Indian J Pharm Sci. 2010;72(3):340-5.

23. Saso L, Valentini G, Leone MG, Grippa E, Silvestrini B. Development of an in vitro assay for the screening of substances capable of dissolving calcium oxalate crystals. Urol Int. 1998;61(4):210-4.

24. Lipschitz WL, Hadidian Z, Kerpcsar A. Bioassay of diuretics. J Pharmacol Exp Ther. 1943;79(2):97-110.

25. Bouanani S, Henchiri C, Migianu-Griffoni E, Aouf N, Lecouvey M. Pharmacological and toxicological effects of Paronychia argentea in experimental calcium oxalate nephrolithiasis in rats. J Ethnopharmacol. 2010;129(1):38-45.

26. Rajagopal G. A simple colorimetric procedure for estimation of citric acid in urine. Indian J Exp Biol. 1984;22(7):391-2.
27. Hodgkinson A. Determination of oxalic acid in biological material. Clini Chem. 1970;16(7):547-57.

28. Senthil D, Subha K, Saravanan N, Varalakshmi P. Influence of sodium pentosan polysulphate and certain inhibitors on calcium oxalate crystal growth. Mol Cell Biochem.1996;156(1):31-5.

29. Park HK, Jeong BC, Sung M, Park M, Choi E, Kim BS, et al. Reduction of oxidative stress in cultured renal tubular cells and preventive effects on renal stone formation by the bioflavonoid quercetin. J Urol. 2008;179(4):1620-6.

30. Zhou XJ, Zhang J, Zhang C, Xu CG. In vitro dissolution of calcium oxalate stones with ethylenediaminetetraacetic acid and snake venom thrombin-like enzyme. Urol Int. 2014;92(3):349-55.

31. Sikarwar I, Dey YN, Wanjari MM, Sharma A, Gaidhani SN, Jadhav AD. Chenopodium album linn. leaves prevent ethylene glycol-induced urolithiasis in rats. J Ethnopharmacol. 2017;195:275-82.

32. Nirumand MC, Hajialyani M, Rahimi R, Farzaei MH, Zingue S, Mohammand $\mathrm{S}$, et al. Dietary plants for the prevention and management of kidney stones: Preclinical and clinical evidence and molecular mechanisms. Int J Mol Sci. 2018;19(3):765.

33. Vermeulen C. Experiments on causation of urinary calculi in: Essays in experimental biology. University of Chicago Press, Chicago. 1962;253-69.

34. Karadi RV, Navneet BG. Effect of Moringa oleifera lam. Root-wood on ethylene glycol induced urolithiasis in rats. J Ethnopharmacol. 2006; 105(1-2):306-11.

35. Lee $\mathrm{YH}$, Wann $\mathrm{CH}$, Jong $\mathrm{KH}$, Luke SC. Testosterone enhances whereas estrogen inhibits calcium oxalate stone formation in ethylene glycol treated rats. J Urol. 1996;156(1):502-5.

36. Iguchi M, Takamura C, Umekawa T, Kurita T, Kohri K. Inhibitory effects of female sex hormones on urinary stone formation in rats. Kidney Int. 1991;56(2):479-85.

37. Khan SR. Animal models of kidney stone formation: An analysis. World J Urol. 1997;15(4):236-43.

38. Orhan N, Onaran M, Sen L, Gonul L. Preventive treatment of calcium oxalate crystal deposition with immortal flowers. J Ethnopharmacol. 2015;163:60-7.

39. Selvam R, Kalaiselvi P, Govindaraj A, Bala MV, Sathish KA. Effect of A. Lanata leaf extract and Vediuppu chunnam on the urinary risk factors of calcium oxalate urolithiasis during experimental hyperoxaluria. Pharmacol Res. 2001;43(1):89-93.

40. Hesse A, Wuzel H, Vahlensieck W. Significance of glycosaminoglycans for the formation of calcium oxalate stones. Ameri $\mathrm{J}$ Kidney Diseases. 1991;17(4):414-9.

41. Soundararajan $P$, Mahesh R, Ramesh T. Effect of Aerva lanata on calcium oxalate urolithiasis in rats. Indian J Exp Biol. 2006;44(12):981-6.

42. Goldberg H, Grass L, Oreopoulos G. Urine citrate and renal stone disease. CMAJ. 1989;141(3):217-21.

43. Grover PK, Resnick MI. Evidence for the presence of abnormal proteins in the urine of recurrent stone formers. J Urol. 1995;153(5):1716-21.

44. Gadge NB, Jalalpure SS. Curative treatment with extracts of Bombax ceiba fruit reduces risk of calcium oxalate urolithiasis in rats. Pharm Biol. 2012;50(3):310-7.

45. Laroubi A, Touhami M, Farouk L, Zrara I, Aboufatima R, Benharref A, et al. Prophylaxis effect of Trigonella foenumgrae cum L. seeds on renal stone formation in rats. Phytother Res. 2007;21(10):921-5. 


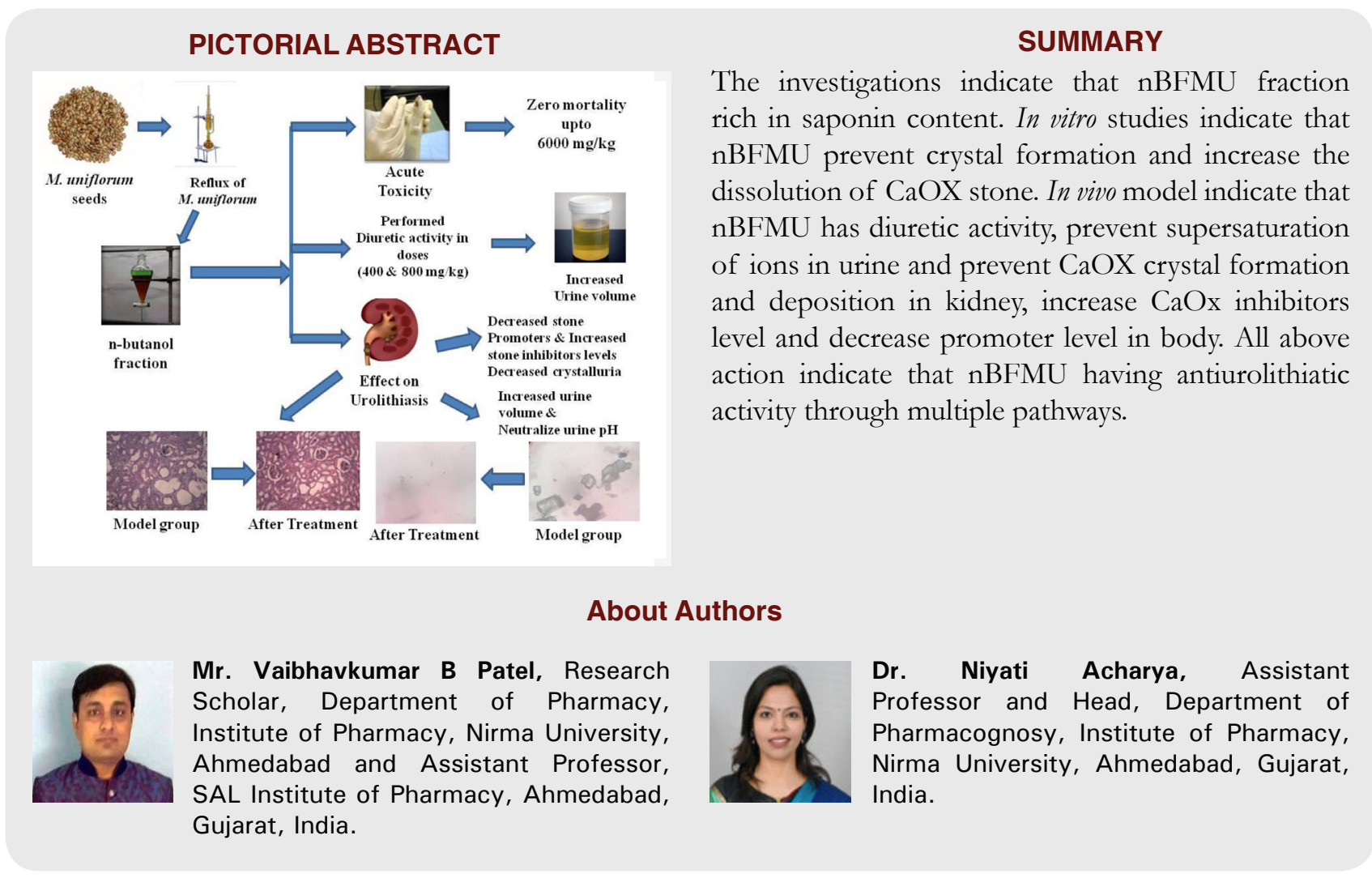

Cite this article: Patel VB, Acharya N. Anti-urolithiatic Activities of Macrotyloma uniflorum Mediated through Multiple Pathway. Indian J of Pharmaceutical Education and Research. 2020;54(2):403-15. 